\title{
Speech, Music, Sound
}




\section{Speech, Music, Sound}

\section{THEO VAN LEEUWEN}




\section{$\approx$}

(C) Theo van Leeuwen 1999

All rights reserved. No reproduction, copy or transmission of this publication may be made without written permission.

No paragraph of this publication may be reproduced, copied or transmitted save with written permission or in accordance with the provisions of the Copyright, Designs and Patents Act 1988, or under the terms of any licence permitting limited copying issued by the Copyright Licensing Agency,

90 Tottenham Court Road, London W1P 0LP.

Any person who does any unauthorised act in relation to this publication may be liable to criminal prosecution and civil claims for damages.

The author has asserted his right to be identified as the author of this work in accordance with the Copyright, Designs and Patents Act 1988.

First published 1999 by MACMILLAN PRESS LTD

Houndmills, Basingstoke, Hampshire RG21 6XS

and London

Companies and representatives

throughout the world

ISBN 978-0-333-64289-4

DOI 10.1007/978-1-349-27700-1

A catalogue record for this book is available from the British Library.

This book is printed on paper suitable for recycling and made from fully managed and sustained forest sources.

$\begin{array}{llllllllll}10 & 9 & 8 & 7 & 6 & 5 & 4 & 3 & 2 & 1\end{array}$

$\begin{array}{llllllllll}08 & 07 & 06 & 05 & 04 & 03 & 02 & 01 & 00 & 99\end{array}$

Editing and origination by Aardvark Editorial, Mendham, Suffolk 
To Tobias Icarus, the other musician in the family 


\section{Contents}

Acknowledgements

1 Introduction

2 Perspective 12

3 Time

4 Interacting sounds $\quad 66$

5 Melody $\quad 92$

6 Voice quality and timbre $\quad 125$

7 Modality 156

8 Afterword 189

Appendix: System networks and sound scripts $\quad 198$

Glossary $\quad 203$

$\begin{array}{ll}\text { Bibliography } & 215\end{array}$

Index 223 


\section{Acknowledgements}

This book would not have existed without the students who took my courses on music and sound at Macquarie University and the London College of Printing. Some are mentioned by name, others will recognize the examples to which they first drew my attention.

Many writers on music and sound have inspired me. Their names are in the bibliography. But two must be singled out, Murray Schafer and Philip Tagg. Those who know their work will recognize their influence throughout the book.

Exactly the same goes for my teachers in the field of linguistics and semiotics, Michael Halliday and Jim Martin, and for my collaborator of many years, Gunther Kress. Their influence is everywhere, and without them none of this could have been written.

Over the years I have also benefited from discussions about speech, music and other sounds with Joyce Belfrage, Philip Bell, John Bernard, Jennifer Biddle, Maria Casas, Michael Chanan, John Clarke, Carolyn Craig, Arthur Delbridge, Laura Lopez-Bonilla and Radan Martinec.

Experimental music adventures with Linda Berry, Rigel Best, Rudi Homburger, John Shand and others were another key source of inspiration and ideas.

The London Institute generously supported the research for this book as part of a three-year grant for work on 'multimodality and the languages of multimedia'. Thanks also to Catherine Gray of Macmillan for her support.

And to Laura for being there and putting up with it all.

Every effort has been made to trace all the copyright holders but if any have been inadvertently overlooked the publishers will be pleased to make the necessary arrangements at the first opportunity. 